Open Access

\title{
Editorial: Language Testing in Asia has been accepted in SCOPUS
}

\author{
Robert Kirkpatrick
}

Correspondence: Itaeditor@gmail.com Gulf University for Science and Technology, Mubarak Al-Abdullah, Kuwait
As we begin our eighth year of publishing, I thought an update on the journal is timely.

In 2017, the scope of the journal was expanded to the whole Asia-Pacific area and thus now welcomes submissions from Oceania as well as Asia and the Middle East.

In 2017, LTA published two important special issues: How does Context Mediate Construct and Content? A political, social and pedagogical analysis of English language testing in Asia, edited by Liying Cheng and Antony Kunnan, and The Common European Framework of Reference for Languages (CEFR) for English Language Assessment in China, edited by Yan Jin and Guoxing Yu. We are currently finalizing Language Assessment Literacy edited by Hassan Mohebbi and Christine Coombe. We welcome proposals for future special issues; please contact myself, Jin Yan or Marius Jung (Marius.Jung@springer.com)

Reviewers are a bedrock of academia, yet recognition of their work remains almost unknown. To help remedy this, a new section has been added to Language Testing in Asia homepage which lists reviewer's names. Also I applaud the new Publons website of which many of the main academic publishers (including SpringerNature) are partners.

The journal is attracting increasing numbers of submissions, and qualified researchers who could be added to our list of reviewers should contact the editors.

Of most note is that LTA has been accepted in SCOPUS Indexing, an indication of the quality of the journal. Coverage will start soon.

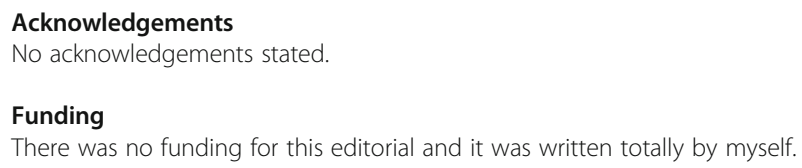

\section{Publisher's Note}

Springer Nature remains neutral with regard to jurisdictional claims in published maps and institutional affiliations.

Received: 7 December 2018 Accepted: 10 December 2018

Published online: 21 December 2018

(c) The Author(s). 2018 Open Access This article is distributed under the terms of the Creative Commons Attribution 4.0 International License (http://creativecommons.org/licenses/by/4.0/), which permits unrestricted use, distribution, and reproduction in any medium, provided you give appropriate credit to the original author(s) and the source, provide a link to the Creative Commons license, and indicate if changes were made. 